\title{
岩石の曲げ強さに関する統計学的研究*
}

$$
\text { 上野五郎** }
$$

\section{A Statistical Study on the Bending Strength of Rock}

by

\author{
Gorō UENO \\ (Yamaguchi University)
}

One of the chief reasons why the bending strength is greater than the tensile strength in rocks, is that fractures can be caused on the parts of the rock also where the tensile stresses are not maximum, by the effect of Griffith cracks distributed at random in a specimen.

For the distribution of the strength of Griffith cracks, the present writer has adopted Weibull's distribution. It is because it has an advantage in being easily treated as compared with the normal distribution introduced by the other investigators, and because the two distributions are closely approximate unless the variation is too great, and the coefficient of uniformity $m$ in Weibull's distribution can be related, by the use of $\Gamma$ functions, to the coefficient of variation $c$.

By applying the theory of the probability of minimum value to the strength of Griffith cracks in a specimen, the distribution of the bending and tensile strengths can be calculated. The both strengths accord with Weibull's distribution, and the ratio of the two strengths are given as the function of $m$.

The experiments the writer carried on with Akiyoshi marble show that the bending and tensile strengths accord with the distribution by Weibull, and the ratio of the two strengths coincides with its theoretical value on a coefficient of confidence of $90 \%$.

Theoretically the coefficients of variation of the two strengths are equal, and it has been tested in the experiment also that those of the experimental values are equal.

(Received Feb. 18, 1960)

\section{1. 緒言}

岩石はりの曲げ破壞試験を行なえば，他のぜい性材 料と同様に曲げ強さは単軸引張強さより数 $10 \%$ 大に 測定されることは周知のことである.

その原因はいろいろあろうが，強さのばらつきが相 当大きいこととも関連して主要な一原因をなすものと して次のことが考えられる。すなわち，曲げ強さはは りを弾性体とみなして曲げモーメントを加えたとき， 引張応力が最大となる引張側表皮部分の破壊時引張応 力として計算されるが, 実際に破壞が発生する箇所は 必ずしも引張側表皮部分とはかぎらず, 力学的弱点の 存在によっては内部から破壊が起こる可能性がある. ことに岩石では一般に相当な空隙率, 吸水率を有する ことや，またたとえば雲母，方解石などを含むときは そこに非常にはく離しやすいいき開面が存在すること

* 原稿受付 昭和 35 年 2 月 18 日

** 正員 山口大学工学部
などから岩石内部に多数の弱点があると考えられる。 個々の弱点の強度は一様でないから内部から破壊する ことも多く，そのときにも表皮部分から破壞したかの ように計算しなければならないことが，曲げ強さの引 張強さより大なることの主要な一因をなしているとい えよう。このことを理論的に取り上げるためには弱点 の分布あるいは破㯖への進行を統計学的に考察する必 要がある。

ぜい性体の強度に関する確率論は従来主として金属 の低温ぜい性などを対象として研究されている，岩石 の強度のばらつきは金属に比べて非常に大きいにもか かわらず，なんとなく見過されているのが現状である が，ばらつきが大きいからこそ鉱山現場の保安その他 の諸問題と関連してそれを統計的に研究しなければな らない。

2. Griffith クラックによる最小值確率論 岩石内部の弱点としてまず考えられるのは数 $\mathrm{mm}^{2}$ 
ないし $\mathrm{m}^{2}$ 程度の面積にわたるき裂であるが,これは試 験片寸法にもよるけれども試験片成形の過程でそれを こわしてしまうし，たとえそうでなくとも破壞試験を 行なったときに明らかに区別されるので, ここで弱点 として考慮するのはいわゆる Griffith クラックである。

\section{(I) 単軸引張強さに対して}

Griffith 理論およびそれとぜい性破壊の諸問題との 関僠はすでに横堀教授によってまとめられたものがあ るが, 同一体積の試験片による単軸引張強さのばらつ きは次式によって説明される。

$$
\begin{gathered}
g(S)=n f(S)\{1-F(S)\}^{n-1} \\
G(S)=\int_{-\infty}^{s} g(S) d S=1-\{1-F(S)\}^{n}
\end{gathered}
$$

ここで $S:$ 引張強さ

$f(S)$ : Griffith クラックの強度の確率密度

$F(S): \quad$ " 累積分布関数

$g(S):$ 試験片強度の確率密度

$G(S)$ ： " 累積分布関数

$n: 1$ 試験片内のクラック数

単軸引張応力に対してクラック強度は確率密度 $f(S)$ の無限母集団を形成し，1 試験片内には母集団からn 個のクラックが抽出されたものとすれば, 試験片の強 度は $n$ 個中最も弱いクラックの強度に等しくなると考 え，そのような $S$ の最小值の分布を計算すれば $g(S)$, $G(S)$ が求められる。1- $G(S)$ は応力 $S$ の状態で試験 片が破壞しない確率であるが，(2)式を变形し

$$
B=-\log \{1-G(S)\}=-n \log \{1-F(S)\}
$$

とおけばこれは risk of rupture と呼ばれる值であっ て取报いに便利である。 $F(S)$ は材料に個有の関数て あるから $S$ に数値を与えたときの $B$ の值は $S$ なる均一 応力分布における試験片の破壊しやすさを表わす。ま た， $G(S)=0 \cdot 5$ ，したがって $B=-\log 0.5$ に対応する $S$ の值は強度の median を示すことになる。

$F(S)$ の表わし方によって $G(S)$ の形も変わってくる. $F(S)$ として正規分布関数をとる人々もあるが，Weibull は

$$
\text { 4) } F(S)=1-\exp \left(-\alpha S^{m}\right)
$$

を採用した． $\alpha>0, m>1$ でともに材料によって決ま る定数である、筆者が数值計算したところではmの值 が 2.5 以上ならばこれは正規分布関数 (変動係数 $40 \%$ 以下）ときわめてよい近似を示している。(4)式を用 いたほうが $G(S)$ の形が簡単であること, 寸法効果が 簡単に表わされることなどの理由により, 以後 $F(S)$ の形として(4)式をとることにする。

(1)，(2)式に(4)式を代入すれば

$$
\begin{aligned}
g(S) & =n \alpha m S^{m-1} \exp \left(-n \alpha S^{m}\right) \\
& =\beta m S^{m-1} \exp \left(-\beta S^{m}\right) \quad(\beta=n \alpha) \\
G(S) & =1-\exp \left(-\beta S^{m}\right)
\end{aligned}
$$

が得られる。普通ぜい性破壞強度の分布は近似的に正
規分布とみなしてよいとされているが，(6)式が形式 的には (4)式で $\alpha$ の代わりに $\beta$ と置きかえたものに等 しく，(4)式の分布が正規分布に近似していることを 考慮すれば，(6)式を採用することは現象的になんら 矛盾しない。

なお, クラックの核生成論の立場から研究された結 果も(6)式と形式的には同じものが得られ，二者の統 合理論が正しい々機堀教授は説明しておられる.

\section{(II) 均一性係数之変動係数}

$m$ は Weibull によって均一性係数と呼ばれ， $m$ の 大なるほどその材料の強度のばらつきは小となる。 $m$ を求めるには $(6)$ 式を変形した

$$
\log [-\log \{1-G(S)\}]=\log \beta+m \log S
$$

を用い，実験值よりその直線を画さ直線の傾斜として 求める直接的方法が考えられるが，むしろ次のような 計算によって変動係数 (標準偏差/平均值) と関係づけ たほうが簡単である。

$\mu, \sigma^{2}$ をそれぞれ $S$ の平均，母分散とすれば

$$
\mu=\int_{-\infty}^{\infty} S g(S) d S, \quad \sigma^{2}=\int_{-\infty}^{\infty} S^{2} g(S) a^{2} S-\mu^{2}
$$

この定積分に $g(S)$ として $(5)$ 式を代入し,$x=S^{m}$ と おけば， $S>0, m>1, \beta>0$ であるから

$$
\begin{aligned}
& \begin{aligned}
\int_{0}^{\infty} S g(S) d S & =\beta \int_{0}^{\infty} x^{1 / m} \exp (-\beta x) d x \\
= & \Gamma\left(1+\frac{1}{m}\right) / \beta^{1 / m}
\end{aligned} \\
& \begin{aligned}
\int_{0}^{\infty} S^{2} g(S) d S & =\beta \int_{0}^{\infty} x^{2 / m} \exp (-\beta x) d x \\
& =\Gamma\left(1+\frac{2}{m}\right) / \beta^{2 / m}
\end{aligned} \\
& \therefore \quad \mu=\Gamma\left(1+\frac{1}{m}\right) / \beta^{1 / m} \\
& \sigma^{2}=\Gamma\left(1+\frac{2}{m}\right) / \beta^{2 / m}-\left\{\Gamma\left(1+\frac{1}{m}\right)\right\}^{2 / \beta^{2 / m}} \\
& c=\sigma / \mu=\left[\Gamma\left(1+\frac{2}{m}\right) /\left\{\Gamma\left(1+\frac{1}{m}\right)\right\}^{2}-1\right]^{1 / 2}
\end{aligned}
$$

したがって

測定値から変動係数 $c$ を求めることは容易であり， $c$ と $m$ とは 1 対 1 の対応をするから Fig. 1 によって $m$ の値を知ることができる。

\section{(III) 曲げ強さに対して}

曲げ破壊のような不均一応力分布に対しては，(3) 式の $B$ の値を微小体積要素について考え，それを積分 することによって試験片全体の $B$ の值を得る。 $F(S)$ として $(4)$ 式を用い, $n=k V(k$ : クラック密度, $V$ : 試験片体積）とすれば

$$
\begin{aligned}
B & =k \int_{V}[-\log \{1-F(S)\}] d V \\
& =k \alpha \int_{V} S^{m} d V
\end{aligned}
$$

以下単軸引張の場合は添字。を, 曲げの場合は $b$ を 


\section{添えることにする．}

いま，Fig. 2 のような曲げを考え，応力ーひずみ関 係が直線的で引張り側と圧縮側とで対称的であると仮 定すれば，

曲げ強さ $S_{b}=\left(l-l_{1}\right) P h / I$

点 $(x, y)$ の応力は

$$
\begin{array}{lll}
o \leqq|x| \leqq l_{1} & \text { では } & S_{1}=(y / h) S_{b} \\
l_{1}<|x| \leqq l & \text { では } & S_{2}=\left\{(l-|x|) /\left(l-l_{1}\right)\right\}(y / h) S_{b}
\end{array}
$$

ぜい性材料では曲げ破壊に圧縮応力の影響を考える必 要がないから $o \leqq y \leqq h の$ 範囲で計算すれば

$$
\begin{aligned}
B & =2 k \alpha\left(\int_{0}^{h} S_{1}^{m} l_{1} d y+\int_{0}^{h} \int_{l_{1}}^{l} S_{2}{ }^{m} d x d y\right) \\
& =k \alpha V_{b} \frac{\left(l_{1} / l\right) m+1}{2(m+1)^{2}} S_{b}{ }^{m}
\end{aligned}
$$

この值は曲げ強さが $S_{b}$ と計算されるような応力分布 状態に执いて, $o \leqq x \leqq l_{1}, y=h$ 以外の箇所加らも破壊 が発生しうることを考慮したときの破壞の危険性を示 す。また，曲げ強さの累積分布関数は

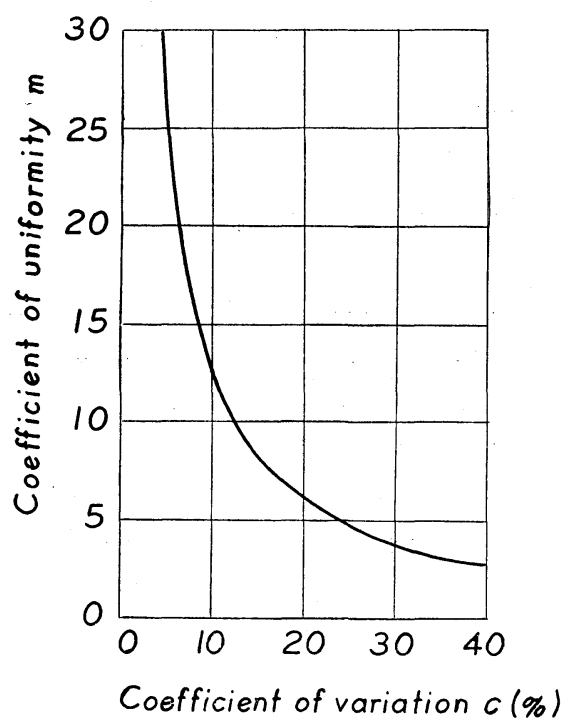

F.g. 1 The relation between the coeffcient of variation $c$ and the coefficient of uniformity $m$

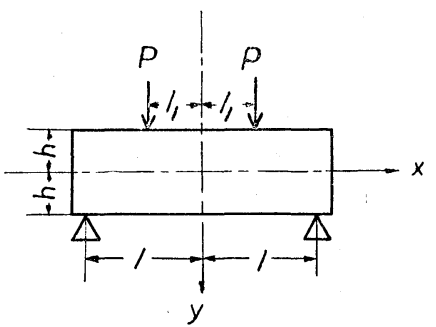

Fig. 2 The specimen of bending test (the moment of inertia of section : I)

$$
\begin{aligned}
G(S) & =\{1-\exp (-B)\} \\
& =1-\exp \left\{-k \alpha V_{b} \frac{\left(l_{1} / l\right) m+1}{2(m+1)^{2}} S_{b}{ }^{m}\right\}
\end{aligned}
$$

これと(6)式を比較すれば， $S_{b}{ }^{m}$ の係数を一 $\beta$ とおく ことにより，曲げ強さもやはりWeibullの分布に従う ことがわかる。

$S_{b}$ の指数mは材料によって決まる定数であるから， (6)，(10)および ( 7 )式より考えて, 同一材料で試験 すれば単軸引張強さも曲げ強さも同一变動係数のばら つきを示さねばならない。なお，これは引張応力が破 壞の原因となっているねじりや圧裂についてもいえる ことである。

いっぼう, 単軸引張強さ $S_{0}$ に対しては

$$
B=k \alpha V_{0} S_{0}{ }^{m}
$$

$B=-\log 0.5$ に対応する $S_{b}, S_{0}$ はその median を与 え，また，mが 2.5 以上ならば Weibull の分布は正規 分布と近似しているので, 強度の median と平均値は ほとんど等しいとしてさしつかえなく，(9)，(11)式 より平均強さの比は

$$
\bar{S}_{b} / \bar{S}_{0}=\left(\frac{V_{b}}{V_{0}}\right)^{-1 / m}\left\{\frac{2(m+1)^{2}}{\left(l_{1} / l\right) m+1}\right\}^{1 / m}
$$

で与えられる。

\section{3. 実験結果と検討}

材料は普通極細目と呼ばれる細粒の秋吉大理石で, 白色に灰色の斑がはいって抢り，比重 $2 \cdot 70$, 吸水率 0.09\%である。

引張試験片は長さ $100 \mathrm{~mm}$ の角柱材料の両端面を新 興通信工業 KK 製 SP-3 接着剤によって軟鋼製端子に 接着した後，円筒研磨機にかけて約 $24 \phi$ の円柱に仕 上げると同時に，両端子中心を結ぶ軸と試験片軸とを 一致させた，小鋼球をはさむことによって摩擦を減少 させた球面座を有するつかみ，および鎖を介してその 端子を引張れば，試験片は曲げこーメントを受けるこ となく単軸引張応力のみを受け，Fig. 3 のような引張 強さの分布を示した。

また，曲げ試験は $25 \times 25 \times 100$ 角柱試験片を用い， Fig. 2 の $2 l=80 \mathrm{~mm}, l_{1} / l=1 / 3$ とした。曲げ強さ の分布を Fig. 4 に示す.

これらの分布に適合性検定を行なった結果は正規分 布に適合し，後に示すように変動係数 $c<40 \%$ である のでWeibullの分布に従うとして取り报ってさしつか えない。

これらの実験值から得られた統計量は Table 1 の ようになる。ここで $s / \bar{S}$ は变動係数 $c$ の点推定量であ るが，引張強さと曲げ強さの関係を明らかにするため にはその区間推定や $c_{0}=c_{b}$ の検定をしなければなら ない。

$c=\sigma / \mu て ゙ s, \bar{S}$ はそれぞれ母標準偏差 $\sigma$, 母平均 $\mu$ 
の推定量であるけれども,一般に $\mu$ の推定精度に比べ $\sigma$ の推定精度はわるいので, $c$ の推定精度も主として $s$ に依存する。また， $c$ は平均值を 1 とみなしたとき の標準偏差であるとも考えられる。一般に分散の形に すれば

$$
\begin{gathered}
\operatorname{Pr}\left\{N s^{2} / \chi_{2}{ }^{2}<\sigma^{2}<N s^{2} / \chi_{1}{ }^{2}\right\}=1-\alpha \\
\text { ただし 自由度 }=N-1 \\
\operatorname{Pr}\left\{\chi^{2}>\chi_{1}{ }^{2}\right\}=1-\alpha / 2 \\
\operatorname{Pr}\left\{\chi^{2}>\chi_{2}{ }^{2}\right\}=\alpha / 2
\end{gathered}
$$

の関係を利用し $\chi^{2}$ 表を用いて $\sigma^{2}$ の区間推定をするこ とができる。したがってこの式の $s$ の代わりに $s / \bar{S}$ を, $\sigma$ の代わりに $c$ 存おきかえてやれば，信頼係数 $1-\alpha$ で

$$
\left(N / \chi_{2}^{2}\right)^{1 / 2} s / \bar{S}<c<\left(N / \chi_{1}\right)^{1 / 2} s / \bar{S}
$$

\section{とみなしても大差ない.}

Table 2 における $c$ の point estimation とは引張

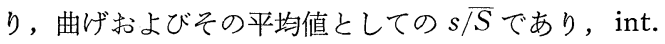
estimation とは(13)式で信頼係数 $90 \%$ \%したときの $c$ の区間の計算值である，更にそれら $c$ の值をもとに

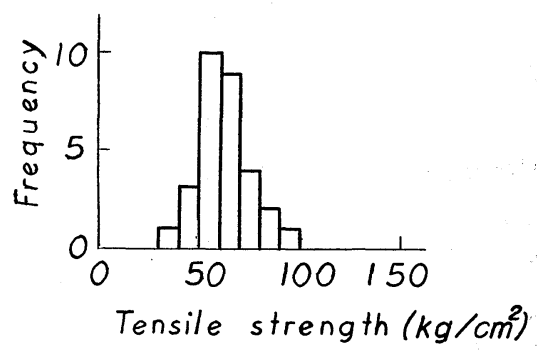

Fig. 3 Histogram of tensile strength of Akiyoshi marble

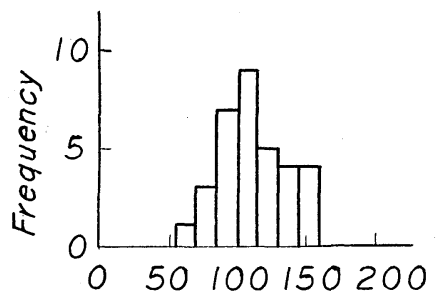

\begin{tabular}{|c|c|c|c|c|c|c|}
\hline & \multirow{2}{*}{$\begin{array}{c}\text { Total } \\
\text { number, } \\
N\end{array}$} & \multicolumn{3}{|c|}{ Strength $\left(\mathrm{kg} / \mathrm{cm}^{2}\right)$} & \multirow{2}{*}{ 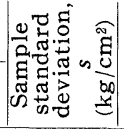 } & \multirow{2}{*}{$\begin{array}{l}s / \bar{S} \\
(\%)\end{array}$} \\
\hline & & $\min$ & $\max$ & $\begin{array}{c}\text { Mean, } \\
\bar{S}\end{array}$ & & \\
\hline Tension & 30 & $37 \cdot 8$ & $90 \cdot 4$ & $62 \cdot 5$ & $11 \cdot 4$ & $18 \cdot 2$ \\
\hline Bending & 33 & $63 \cdot 8$ & $148 \cdot 4$ & $110 \cdot 7$ & $22 \cdot 4$ & $20 \cdot 2$ \\
\hline
\end{tabular}

\section{Bending strength $\left(\mathrm{kg} / \mathrm{cm}^{2}\right)$}

Fig. 4. Histogram of bending strength of Akiyoshi marble

Table 1 Statistical values (Akiyoshi marble)
して Fig. 1 より求めた $m$ の值, 実験に関与した試験 片体積 $V$ を考虑しつつ(11)式より求めた $S_{b} / S_{0}$ の值を その下方に掲げた， $m$ の推定值としては $6 \cdot 0$, 区間推 定としては引張りと曲げで重なっている区間をとって $4 \cdot 9 \sim 7 \cdot 3$ (信頼係数 $90 \%$ ) をとるべきであろう．また， それに基づく $\bar{S}_{b} / \bar{S}_{0}$ の值はそれぞれ $1 \cdot 73$ および $1 \cdot 62$ 〜1.88である. いっほ方，実測されたTable 1 の $\bar{S}_{b}$, $\bar{S}_{0}$ から求めた比は 1.77 であり，信頼係数 $90 \%$ で区間 推定すれば $1 \cdot 66$ ～1.88 が得られるから両者は非常に よい一致を示したとしてよいであろう。

なお，前述のようにWeibullの分布からの結果とし て, 単軸引張強さの分布も曲げ強さの分布も同一変動 係数を持たなければならない. Table 2 で単軸引張り と曲げとの平均としての $c$ の值考考えたのもその前提 があったからである。 $c$ を一種の標準偏差とみなし, $c_{b}{ }^{2}=c_{o}{ }^{2}$ という等分散の仮定を $F$ 検定してみると

$$
\begin{aligned}
& F=\frac{N_{b} c_{b}{ }^{2} /\left(N_{b}-1\right)}{N_{0} c_{0}{ }^{2} /\left(N_{0}-1\right)}=1 \cdot 22 \\
& \alpha=0 \cdot 10 \text { で } F_{0}=1 \cdot 86 \quad(\alpha \text { : 危険率 })
\end{aligned}
$$

$F<F_{0}$ であるから, 危険率を $10 \%$ とっても等分散 の仮定は臬却でさないことになる。したがって，単軸 引張強さと曲げ強さは同一変動係数を持つとしてさし つかえない.これはWeibullの式を導入したことの正 当性を消極的にではあるが支持する一つの証拠だとい えよう.

岩石の曲げ強さが単軸引張強さより大である原因は 決して一つではないが，上述の確率論が実験とよい一 致を示したことは Griffith クラックあるいはクラック の核生成の問題がその主要な一原因であることを証明 している。その他の原因としては，たとえば既に堀部 教授がはりの中立軸の移動によるとして実験的に移動 を確かめておられる. 山口大学石原助教授と筆者が秋 吉大理石 (細粒) について測定したところでは，応力ひずみ曲線の形は引張応力下と王縮応力下では相当異 なるようである。これは当然堀部教授のいわれる中立 軸の移動をきたすものと思われるので, それを考虑に

Table 2 The coefficient of variation $c$, the coefficient of uniformity $m$, and the ratio of mean strengths $\bar{S}_{b} / \bar{S}_{0}$. (Akiyoshi marble, $V_{b} / V_{0}=1 \cdot 21$ )

\begin{tabular}{c|c|c|c|c|c}
\hline & \multicolumn{2}{|c|}{ Point estimation } & \multicolumn{2}{c}{ Interval estimation } \\
\cline { 2 - 5 } & Tension & Bending & Mean & Tension & Bending \\
\hline$c(\%)$ & 18.2 & 20.2 & 19.2 & $15.1 \sim 23.2$ & $16.2 \sim 25.4$ \\
\hline$m$ & 6.4 & 5.7 & 6.0 & $7.9 \sim 4.9$ & $7.3 \sim 4.5$ \\
\hline $\bar{S}_{b} / \bar{S}_{0}$ & 1.69 & 1.77 & 1.73 & $1.57 \sim 1.88$ & $1.62 \sim 1.95$ \\
\hline
\end{tabular}


入れれば(9)式の右辺の係数は修正を必要とするであ ろう.

また， $m$ の值は $\bar{S} \propto V^{-1 / m}$ の形で寸法効果に関与す るからその面から実験的に研究することは, 大理石以 外の岩種に実験を広げることとともに今後に残された 興味ある課題である。

\section{4. 結言}

（1）Griffith クラックの強度が Weibull の分布に 従うとの仮定に基づく最小値確率論あるいはクラック の核生成論から導かれた, 曲げ強さと単軸引張強さの 平均値の比は(12)式で表わされる．秋吉大理石(細粒) による実験値は理論值とよい一致を示す。

(2) 变動係数 $40 \%$ 以下ならば正規分布はWeibull の分布 (4)あるいは(6)と近似しており, 秋吉大理石 (細粒)では引張強さ, 曲げ強さともにWeibullの分布 に従うとしてさしつかえない。
（3）Weibull のいう均一性係数mの值は（7)式に よって变動係数 $c$ と関係づけられる. 同一材料ならば 引張強さに対しても曲げ強さに対しても无の值は变わ らず, したがって変動係数も等しい. 秋吉大理石（細 粒)では危険率を $10 \%$ にっても両变動係数に有意差 はないと検定された。

終りにいろいろ御指導をいただいた山口大学石原助 教授, 曲げ強さのデータを供与していただいた同学荻 野助教授，ならびに実験, 計算に御協力を受けた小池, 高野両君に深く感謝の意を表わします。

\section{参考 文 献}

1) 横.堀, 材料強度学 (昭 30 )

2) " ，材料試跧， 5，32(昭31)など

3) Frenkel and Kontorova, J. Phys. U.S.S.R., 1, 108 (1943)

4) Weibull, Ing. Vetenskaps Akad. Hand., No. 151 (1939), Itid., No. 153 (1939)

5) 堀部, 日本鉱業会誌, 71, 806 (昭30)

\section{有 機 材 料}

アクリル樹脂の破壊現象 (Fracture Phenomena and Molecular Weight in Polymethyl Methacrylate) S.B. Newman and I. Wolock, J. Appl. Physics, Vol. 29, No. 1 (Jan.1958) pp. 49〜52, 因 7, 表なし. ポリマーの破断面の実験的研究はその粘弹性挙動に 関連した破壞機構の研究に, 特に他の工業材料の破壞 特性との類似性に役立つ.ポリマーでもその破壊に影 響する因子としては, 荷重状態, ひずみ速度, 温度, 湿度などの外的環境, 分子量とその分布なぞがあげら れるがアクリル樹脂注型品について 5 種類の分子量の 異なる試料について一定引張速度における破壞（温度 $23{ }^{\circ} \mathrm{C}$, 相対湿度 $50 \%$ ) と分子量の関係が検討されてい る. 破断面には銀蒸着を施して光学頭微鏡で破断面の 状態が調べられている。破断面には明暸な 2 種類の異 なった破壊機構が存在することを示唆していて，引張 速度の影響に関しては Zandman の結果と類似して いる。

(伊藤勝彦)
急冷焼入れポリエチレンの結晶化回復 (Crystalline Recovery of Quenched Polyethylene) R.L. Collins, J. Polym. Sci., Vol. 27, No. 115 (Jan. 1958) pp. $75 \sim 82$ 囝 2 , 表 2 .

中圧法ポリエチレン Marlex 50 の溶融物を $25^{\circ} \mathrm{C}$, $66^{\circ} \mathrm{C}$ および $106 \cdot 4^{\circ} \mathrm{C}$ に急冷焼入して, 時間 $t$ ととも に結晶化が回復進行するのを陽子磁気共鳴で測定する と, $t=0 \cdot 1 \sim 1000$ 時間の範囲では結晶化度 $X=A+$ $B \log t$ の関係が成り立つ. 結晶化の速度決定因子が 無定形部分の拡散であると仮定すると係数 $B$ は拡散係 数と同じ温度变化をするはずであり, Marlex 50 につ いてこの仮定の妥当性が示されている．また平衡結晶 化度の近似式として $180^{\circ} \mathrm{C} に 1$ 時間保った後指数関 数的に冷却させて $X$ を測定した值が選ばれている。こ の結果 Marlex 50 では平衡結晶化度に達するには焼 鈍温度 $100^{\circ} \mathrm{C}$ では数千時間を要する。（伊藤勝彦） 